УДК 656.62.073.235 - 027.1 (477)

JEL L91, R48, R49

LASHUTINA V.O.,

Postgraduate student

Market of Transport Services Department

Institute of Market Problems and Economic \& Ecological Research of

the National Academy of Sciences of Ukraine,

Frantsuzkyi boulevard, 29, Odessa, Ukraine, 65044

E-mail: leralashutina@gmail.com

ORCID: 0000-0002-3671-6719

\title{
PERSPECTIVES FOR THE DEVELOPMENT OF CONTAINER CARGO TRANSPORTATION INLAND WATERWAYS OF UKRAINE
}

Topicality. The river potential of Ukraine has great prospects in the direction of connecting with Europe at the expense of increasing the transit capacity of the Danube and the Dnieper rivers taking into account the access to the Black Sea. River transport has a number of advantages over land, in particular: ready natural ways; use of water flow; the ability to transport any cargo and passengers simultaneously; safety and environmental friendliness; high bandwidth; high degree of reliability and timeliness of delivery; low cost of transportation, which leads to fuel economy, etc. It should be noted that to date, taking into account the uplift tariffs for transportation by rail and inconvenience of use of motor transport, organization of container service on the Dnieper is the most promising and in demand.

Aim and tasks. The aim of the article is to determine the organizational and economic bases of river container transportation in Ukraine. In accordance with the stated aim, it is necessary to analyze the cargo base of river container transportation in Ukraine; to formulate priorities of development of river navigation of Ukraine; to substantiate the efficiency of using container technology of cargo transportation by inland waterways of Ukraine.

Research results. The complex of measures for the development of container cargo transportation by inland waterways of Ukraine was proposed, the analysis of the market of river container transportations in Ukraine in comparison with the countries of the European Union and the USA was carried out, the main problems of development of inland water transport were identified and measures for their further development and operation of inland waterways of Ukraine taking into account the prospect of their integration into the European transport network.

Conclusion. Ukraine has significant potential for organizing logistics schemes for cargo transportation involving river transport in several directions. The presence, albeit somewhat obsolete, a powerful infrastructure base, a convenient geographical location and the availability of traffic flows that can potentially be transported by inland waterways, creates the preconditions for the restoration and development of this transport area.

Keywords: inland waterways, container transportation, feeder container transportations, multimodal transportations, river transport.

ЛАШУТІНА В.О.,

Аспірант відділу ринку транспортних послуг

Інститут проблем ринку та економіко-екологічних досліджень НАНУ,

Франиузький б-р, 29, м. Одеса, Украӥна, 65044

E-mail: leralashutina@gmail.com

ORCID: 0000-0002-3671-6719

\section{ПЕРСПЕКТИВИ РОЗВИТКУ КОНТЕЙНЕРНИХ ВАНТАЖОПЕРЕВЕЗЕНЬ ВНУТРІШНІМИ ВОДНИМИ ШЛЯХАМИ УКРАЇНИ}

Актуальність. Річковий потенціал України має великі перспективи в напрямку сполучення з Свропою за рахунок підвищення прохідної спроможності річок Дунай та Дніпро з урахуванням виходу в Чорне море. Річковий транспорт має низку переваг перед сухопутним, зокрема: готові природні иляхи; використання течї води; можливість одночасно транспортувати будь-які вантажі й пасажирів; безпечність та екологічність; висока пропускна спроможність; високий ступінь надійності i вчасність доставки; низька вартість перевезення, щзо призводить до економії палива тощзо. Необхідо відмітити, щзо на сьогоднішній день, 3 урахуванням підняття тарифів на перевезення залізницею та незручністю використання автомобільного транспорту, організація контейнерного сервісу на Дніпрі є найбільш перспективною та затребуваною. 
Мета та завдання. Метою статті є визначення організаційно-економічних засад розвитку річкових контейнерних перевезень в Украӥні. Відповідно до визначеної мети необхідно проаналізувати вантажну базу здійснення річкових контейнерних перевезень в Україні; сформулювати пріоритети розвитку річкового судноплавства Украӥни; обгрунтувати ефективність використання контейнерних технологій вантажоперевезень внутрішніми водними шляхами Украӥни.

Результати. Запропоновано колплекс заходів щуодо розвитку контейнерних вантажоперевезень внутрішніми водними шляхами Украӥни, був проведений аналіз ринку річкових контейнерних перевезень в Україні порівняно з краӥнами Європейського Союзу та США, виявлені основні проблеми розвитку внутрішнього водного транспорту та запроваджені заходи щүодо їх щзодо подальшої розбудови та експлуатації внутрішніх водних иляхів України з урахуванням перспективи їх інтеграції до європейської транспортної мережі.

Висновки. Україна має значний потенціал для організації логістичних схем перевезення вантажів за участю річкового транспорту на декількох напрямках. Наявність, хоча й дещяо застарілої, потужної інфраструктурної бази, зручне географічне розташування та наявність вантажопотоків, щзо потениійно можуть бути перевезені по внутрішніх водних шляхах створює передумови для відновлення та розвитку цього транспортного напрямку.

Ключові слова: внутрішні водні иляхи, контейнерні перевезення, фідерні контейнерні перевезення, мультимодальні перевезення, річковий транспорт

Problem statement and its connection with important scientific and practical tasks. The inland waterways of Ukraine include the rivers defined by the European Agreement on the most important inland waterways of international importance. There are the Danube, Dnipro, and Dniester rivers among them. Ukraine has a very high river shipping potential with a length of waterways of approximately $6200 \mathrm{~km}$, which are suitable for operation. In general, Ukraine's rivers can transport 10-12 million tons of cargo per year. However, the existing infrastructure of the river moorings does not meet modern international technical specifications and standards and is used only for 5-10\% of its capacity [1].

The statistical data indicate a threefold decrease in volumes of cargo transportation by water transport over the past 10 years. There is a complete shift of cargo flows towards rail and road transport. This process was promoted by low railway tariffs and the lack of control over allowable loads for freight road transport. As a result, the critical condition of highways and deterioration of a railway car fleet. In this case, river shipping, which is the cheapest and most ecological type of transportation, is almost not used. The current situation is a serious problem and, at the same time, an opportunity, as river transport in the structure of all transport has the greatest potential for growth.

Analysis of recent publications on the problem. The scientific works of Boniar S.M., Vinnikov V.V., Zerkalov D.V., Koba V.H., Kotlubai O.M., Kucheruk H.Yu., Prymachov M.T., Savelieva I.V. and Tymoshchuk O.M. are devoted to the studying the issue of the development of water transport enterprises. Studies on water transport mostly relate to the management of it, increase competitiveness among other modes of transport, as well as economic relations in this area. However, in Ukraine, the problem of an efficient choice of transportation method remains unresolved, which, in turn, develops one mode of transport and strikes the other.

Allocation of previously unsolved parts of the general problem. Ukraine is an integral part of all European processes. Due to its geopolitical position, Ukraine is a strategic player in the system of European inland shipping, being at the junction of the most important transport routes connecting the West and the East, North and South. River transport is recognized the most economical and environmentally friendly transport, and the lack of state regulation in the field of inland water transport of Ukraine and the outdated ideology of the economic activity of ports significantly influenced its development, which led to a significant lagging behind the European pace. All countries of the world use all modes of transport proportionally, so that there is no overload of one mode of transport and idle time in the work of another [2].

Formulation of research objectives (problem statement). The main goal of the research is to substantiate measures for the development of container cargo transportation by inland waterways of Ukraine, as well as to analyse the European and world experience of river container transportations. Container transportation is one of the priorities of the development of the transport industry of any country that uses sea and river transport in the international logistics system in the conditions of globalization of the world economy and market competition.

An outline of the main results and their justification. The efficiency of containers in the national economy and areas of their economic exploitation depend on volume of transportation (load capacity) and size of individual shipments, type of cargo and structure of cargo flows, transportation distance, availability of 
access roads and goods handling equipment in places of loading and unloading, type and load carrying capacity of the rolling-stock, delivery forms of suppliers and consumers, their freight forwarding services and etc.

Containerization is one of the most important directions of development, rationalization and optimization of transport processes. Container transportations allow to set free the cargo owner from the need for transport packaging and marking, to eliminate the costs of handling and warehousing in multimodal transportation. The Asian, European and Mediterranean countries are the brightest example of the modern way of using container transportation. Today in Europe about $70 \%$ of all goods are transported in containers. Over the past decade, there has been a significant increase in volumes of transportation by maritime and river fleets of massive dangerous cargoes - bulk (hand, coke, mineral fertilizers, etc.), petroleum products, chemicals and etc. Even these types of cargo are already transported in containers. This approach to transportation provides the opportunity to provide physical and commercial storage of cargo [3]. This approach provides an opportunity for ports to expand the hazardous goods handling nomenclature without negative impact on the environment.

Interaction between countries of Asia and Europe is carried out by water ways on a global level, so ports are considered as the main connecting link of different modes of transport in international container transport chains. The success of the leading European ports of the world for container handling is due to the effective usage of the potential of inland waterways.

Today, Ukraine actively develops this trend and works with the European Commission and international companies to make a clear mechanism for work on the development of inland waterways and harmonization the legislative framework in this sector of transport. The development of inland waterways is a priority direction of the Ministry of Infrastructure of Ukraine, and renovation of full navigation on the Dnipro, Danube and Dniester rivers is one of the main tasks. But there are issues that constrain the development of cargo transportation by inland waterways of Ukraine. First, it is the adoption of the Law of Ukraine "On Inland Water Transport". Inland waterways of Ukraine are not used to the full extent due to the imperfection of the regulatory framework in the field of inland water transport, most of legal relations are regulated at the level of sub-legal normative acts. The processes of development of inland waterways take place in separate directions on the basis of diversified laws without taking into account the features of the inland water transport industry [1]. Secondly, this is a significant level of depreciation of the infrastructure of inland waterways of Ukraine, insufficient amount of modern terminals, lack of fleet for cargo transportation and insufficient depths on the Dnipro, Danube and Southern Bug rivers.

The market for inland waterways transportation in Ukraine is estimated at 6.5 million tons per year and is characterized by an increase in volumes of transportation, mainly due to transportation of grain and metal. At the same time, the market has the potential for a threefold increase to 2020 year and a fivefold increase to 2035 year. The main driver of the market is the growth of exports of grain and metallurgical products from central Ukraine, in particular the transportation of raw materials to the Black Sea ports. The main constraining factors for market growth are high cost of transportation to the river and transhipment, non-competitive price of inland waterways transportation in comparison with the railways, high capital costs for the acquisition or building of a fleet, low potential amount of voyages and low speed of rotation of ships due to infrastructure restrictions - the absence of guaranteed depths, the risk of accidents on gateways and etc. There are 4 operators on the market. Ukrrichflot and NIBULON are two of them. These companies are vertically integrated and they are carriers, cargo owners, owners of river terminals and shipbuilders at the same time. Infrastructure of inland waterways suffers from chronic underfunding, first of all, locks on the Dnipro river. Due to the lack of dredging, the length of the shipping routes since 1990 has decreased by 2.5 times and is $1600 \mathrm{~km}$ instead of $4000 \mathrm{~km}$. Underdeveloped infrastructure reduces the investment attractiveness of the river industry [4].

At the same time, the density of river navigable waterways decreased by 1.75 times, the intensity of cargo transportation - by 3 times and the transport of passengers - by 7.5 times. The analysis of the resource potential of the river fleet of Ukraine has shown that $80.8 \%$ (1648 units) of river vessels are usable, the remaining $19.2 \%$ (392 units) are unsuitable for operation. In the structure of vessels, that suitable for exploitation, the largest share $46.7 \%$ (770 units) and $44.4 \%$ (731 units) is formed by service auxiliary and transport vessels. There are also technical ships with a share of $6.9 \%$ (113 units) and special purpose vehicles with a share of $2.1 \%$ (34 units). The carrying capacity of transport vessels is 899,8 thousand tons, and passenger capacity is 16,4 thousand passengers [5]. The average lifespan of the river fleet is $21-25$ years old, with only $18 \%$ of the fleet having an age less than 20 years. The technical condition of the river 
fleet is constantly deteriorating. A significant amount of vessels is approaching a critical period of service. In the structure of the fleet, the largest share of outdated vehicles falls on cargo and passenger vessels (97.1\%), bulk ships $(89.5 \%)$ and dry cargo vessels $(84.4 \%)$. In the structure of a special purpose fleet, the largest share of outdated vehicles falls on raiding and shunting vessels, tugboats $(90.7 \%)$, technical vessels $(79,6 \%)$ and service auxiliary vessels $(77,7 \%)$. As a result, over the last 5 years, the total volume of cargo transportation has decreased by 3 times. In 1990, the volume of internal transportation by river in Ukraine amounted to almost 67 million tons per year, at present the figure has decreased to 8 million tons.

According to table 1, in 2017, 8,095 million tons of cargo were transported by the Dnipro river, which is 1.7 million tons ( $26 \%$ ) more compared to 2016 . The container turnover on the Dnipro river increased by $13.8 \%$ compared with 2016, 1948 containers were transported in 2017. The number of ship locks by the Dnipro river for the navigation period in 2017 increased by $13 \%$ - to 13408 compared with 2016. In this case, the amount of cargo ships increased by $9 \%$. In total, the amount of foreign vessels increased by $20 \%$, coastal vessels - by $12 \%$. In 2016, 6.4 million tons of cargo and 1711 containers were transported across the Dnipro river. In 2016, Ukrrichflot transported 1.7 million tons of cargo by inland waterways of Ukraine, 2 million tons were transported by NIBULON (including 300 thousand tons - the Southern Bug river) [6].

In 2018, the river ships transported over 3.1 million tons of grain cargoes by the Dnipro river, while a year earlier - 2.6 million tons $(+15.3 \%)$. In addition, 850 thousand tons of grain were transported along the Southern Bug river. NIBULON transported more than 1.7 million tons of grain by the Dnipro river, Ukrrichflot transported 500 thousand tons of cargo in the cabotage. The replenishment of the fleet, that able to work in the cabotage, contributed the growth of grain transportation. The company "NIBULON" launched on the water two one hundred meter non-self-propelled vessels with a capacity of 5000 tons and two multipurpose tugboats in 2018 [8].

Transportation of cargo on the Dnipro river, 2013-2017 (thousand tons) [7]

\begin{tabular}{|c|c|c|c|c|c|}
\hline Indicator & $\begin{array}{c}\text { For the navigation } \\
\text { period of 2013 }\end{array}$ & $\begin{array}{c}\text { For the navigation } \\
\text { period of 2014 }\end{array}$ & $\begin{array}{c}\text { For the navigation } \\
\text { period of 2015 }\end{array}$ & $\begin{array}{c}\text { For the navigation } \\
\text { period of 2016 }\end{array}$ & $\begin{array}{c}\text { For the navigation } \\
\text { period of 2017 }\end{array}$ \\
\hline Total & 3564 & 4384 & 4702 & 6435 & 8085 \\
\hline Grain & 1383 & 1489,9 & 1768,7 & 1999,0 & 2663,0 \\
\hline
\end{tabular}

A number of systemic actions, that contribute to increasing the competitiveness of river transport:

- adoption of the Law of Ukraine "On Inland Water Transport";

- development and implementation of the system of intersectoral goods and transport balances;

- amendments to the regulatory documents of the Ministry of Infrastructure to support domestic water transport operators.

Container transportation on the Dnipro river is a potential market niche for the development of inland water transport, due to the transfer of cargo flows from highways to inland waterways. The attraction of container cargo flows to the river ports of Ukraine provides an opportunity to increase the volumes of cargo transportation by river transport, which, in turn, will increase the profitability of transportation and reduce the burden on land transport routes. As a result, the Dnipro river and its ports will become more interesting for attracting new investors.

Feeder container transportations will be implemented along the Dnipro river with the participation of container lines, sea container terminals, Dnipro, Zaporizhzhya and Kyiv river ports. These transportations involve the delivery of imported containers to / from Odessa, their reloading to road / rail transport and further transportation to highly developed regions of the country (Kyiv, Dnipro, Zaporizhzhya, Poltava, etc.). According to the calculations of the Ministry of Infrastructure of Ukraine, the potential volume of attraction to the river of cargoflow (metal products of various nomenclature, consumer goods (in the future), non-ferrous metals, oils, etc.) is 40 million tons, one additional million tons of cargo, transported along the river, can save 750 million UAH. The development of shipping will stimulate the development of the shipbuilding industry and other related industries (one job at a shipbuilding plant provides another five jobs in related industries).

Containers have a number of advantages. They can be downloaded $30 \%$ more than a lorry. This is a closed container, so moisture, precipitation and robbers do not have access to its contents. Depending on the 
logistic scheme, in some areas transportation in a container is cheaper than transportation by road by 15 $40 \%$, and transportation equates to the time frame of delivery by car [11].

Table 2

\section{SWOT Analysis of cargo transportation along the Dnipro river}

\begin{tabular}{|c|c|}
\hline & weannesses \\
\hline $\begin{array}{l}\text { le geographical location of the river port } \\
\text { re. } \\
\text { ence of a significant cargo base in the areas } \\
\text { the river. } \\
\text { ive cost of logistics. } \\
2 \text { emissions. } \\
g \text { of cargo traffic on a national scale. }\end{array}$ & $\begin{array}{l}\text { 1. Limited navigation period. } \\
\text { 2. High indicator of infrastructure } \\
\text { depreciation. } \\
\text { 3. Vacuum of right regulation. } \\
\text { 4. Lack of commodity and transport balances. } \\
\text { 5. Low transparency in the provision of } \\
\text { customs services. }\end{array}$ \\
\hline & \\
\hline $\begin{array}{l}\text { 1. High probability of increasing the cost of rail or auto- } \\
\text { logistics. } \\
\text { 2. Improvement of customs regulation and sectoral } \\
\text { legislation. } \\
\text { 3. Building of specialized container terminals and } \\
\text { modern fleet. }\end{array}$ & $\begin{array}{l}\text { 1. Political instability in Ukraine. } \\
\text { 2. Lack of strategic planning in the transport } \\
\text { sector at the state level. } \\
\text { 3. Low efficiency of customs regulation } \\
\text { reforms and development of sectoral } \\
\text { legislation. }\end{array}$ \\
\hline
\end{tabular}

Source: Author's development

In Ukraine, multimodal transportation is not evolving due to the following reasons:

- imperfect regulatory framework;

- imbalances between the levels of capacity development of the ports for the processing of cargoes and the railway infrastructure adjacent to them, that hinder the development of container and piggyback transportations;

- high risks of multimodal operators in the organization of multimodal transportation at considerable distances involving two or more modes of transport;

- the absence of a developed network of transport and logistics centers in Ukraine, as well as institutes of multimodal (logistics) operators;

- lack of highly professional and experienced specialists in multimodal transportation;

- the absence of a representative network of national forwarding companies abroad, which would ensure a high degree of coherence of the actions of all participants in the transportation of goods and protect the interests of the state outside of Ukraine.

Contrary to Ukrainian practice of the decline of container traffic, for example, the European Union has about 750 inland ports, over 100 of which operate container terminals and the total number of which is constantly growing. The annual volume of cargo handling in 50 of the largest ports is over 1 million tons of cargo, almost 40 ports are both domestic and seaports [9]. The United States inland waterway system includes over 200 ports and 12,000 miles of navigable waterways. Using inland waterways helps reduce transport costs by about $\$ 12.5$ billion annually and creates more than 250,000 jobs. More than $28,740,000$ containers are shipped every year at United States maritime ports [10], and river ports, considered to be nationally significant, are used for the development of United States agricultural districts and their links with global markets.

In 2018, container transportations by the Dnipro river showed a drop and amounted to only 75 units, 1948 containers were transported in 2017. A significant part of the containers, transported in 2016, were containerized with cargo of the company "Interpipe" - 1528 containers (about 37 thousand tons) But in 2017, there were 826 containers (about 18.8 thousand tons).

In order to develop multimodal (combined) transportations in Ukraine, it is necessary to implement the following measures.

1. To create a legal basis for the development of mixed (combined) transportations and its integration with the European multimodal network.

2. To increase the competitiveness of Ukrainian ports in order to attract additional volumes of 
3. To prepare the necessary technical, organizational, technological and legal basis for widespread introduction of the principle of a one-stop shop for the customs clearance of cargoes crossing the state border, the introduction of an electronic declaration system for goods using an electronic digital signature.

4. To train highly qualified specialists in Ukraine in the field of the organization of mixed (combined) and multimodal transportations by training of specialists in higher educational establishments.

The development of multimodal (combined) transportations will contribute to the integration of Ukraine's transport system into the global transportation system, which will allow the full usage of its transit potential.

Conclusions and perspectives of further research. The reduction of the domestic river fleet, the technical and moral obsolescence of ships, the unsatisfactory condition of infrastructure, in particular the approaching of a large number of hydraulic structures to the emergency condition, the lack of funds for state financing of river infrastructure development, and the lack of interest of private investors to participate in its development create a threat to the further decline of river transport in Ukraine. While in the world there is a tendency towards the revival of navigation by inland waterways as the most economical and environmentally friendly mode of transport, the volumes of cargo and passengers are reduced in Ukraine, the number of merchant vessels is decreasing, including under the national flag, accordingly, revenues to state and local budgets, received from the work of the fleet, are reduced.

Based on the proposed measures, an effect will be expected, which will allow: railways to the river;

to unload the ground infrastructure due to redistribution of goods from highways and

$\checkmark \quad$ to develop and create new stevedoring capacities on inland water transport;

$\checkmark \quad$ create new workplaces;

$\checkmark \quad$ to develop related industries, first of all, shipbuilding.

Expansion of containerization on river transport will promote efficient organization of production in the system of multimodal transport. It will significantly increase the volume of cargo transportation across the territory of Ukraine, will increase the competitiveness of the country in the world transport services market, the development of a network of existing transport corridors, the integration of Ukraine's transport infrastructure into the world transport system.

\section{ЛІТЕРАТУРА}

1. Розвиток внутрішніх водних шляхів - дорога до євроінтеграції [Електронний ресурс] / Центр транспортних стратегій: оф. веб-сайт. URL https://cfts.org.ua/blogs/rozvitok_vnutrishnikh_vodnikh_shlyakhiv_doroga_do_evrointegratsi_251. Назва 3 екрана.

2. Марченко О.В., Бугайова Д.О. Водні перевезення в Україні та закордоном: розвиток інфраструктури та правовий статус портів [Електронний ресурс] // Порівняльно-аналітичне право. 2017, № 4. C. 106-108. URL : http://www.pap.in.ua/4_2017/30.pdf

3. В Черноморском бассейне ожидается рост фидерных перевозок // Порты Украины. 2016, № 8.

4. Вантажні перевезення внутрішніми водними шляхами [Електронний ресурс] / Oфіс ефективного регулювання: оф. веб-сайт. http://www.eu4business.eu/files/medias/regulation.gov_.ua_vantazhni_perevezennya_vnutrishnimi_vodnimi _shlyahami_final.pdf

5. Український річний флот [Електронний ресурс]. URL : http://ukrrichflot.ua/ua.

6. Вантажоперевезення по Дніпру збільшилися на $26 \%$ у 2017 році [Електронний ресурс] / Центр транспортних стратегій: оф. веб-сайт. https://cfts.org.ua/news/2018/01/18/gruzoperevozki_po_dnepru_uvelichilis_na_26_v_2017_godu_45059. Назва з екрана.

7. Річкова інформаційна служба України [Електронний ресурс]. URL : https://ukrris.com.ua/ris/fairway/waybills/index.php

8. Хто, скільки і чого перевіз річками України у 2018 році [Електронний ресурс] / Порти України: оф. веб-сайт. URL : https://ports.com.ua/uk/articles/kto-skolko-i-chego-perevez-na-rekakhukrainy-v-2018-godu. - Назва з екрана.

\section{9}


9. Шандрівська О. Є., Висоцький М., Крикавський Є.В. Дослідження стратегічних перспектив розвитку річкових портів України. 2017.

10. Найбільші порти США [Електронний ресурс] / Bce про CША. URL : http://usainfo.com.ua/ports-usa/symbol/ports

11. Контейнерні перевезення - ключ до європейського ринку [Електронний ресурс] / Залізничний інформаційний портал медіацентр «Магістраль»: оф. веб-сайт. URL : https://info.uz.ua/analitika/konteynerni-perevezennya-klyuch-do-evropeyskogo-rinku. Назва з екрана.

\section{REFERENCES}

1. Rozvytok vnutrishnikh vodnykh shljakhiv - dorogha do jevrointeghraciji [The development of inland waterways is a road to European integration] cfts.org.ua. Retreived from: https://cfts.org.ua/blogs/rozvitok_vnutrishnikh_vodnikh_shlyakhiv_doroga_do_evrointegratsi_251 [in Ukrainian]

2. Marchenko O.V., Bughajova D.O. (2017).Vodni perevezennja v Ukrajini ta zakordonom: rozvytok infrastruktury ta pravovyj status portiv [Water transportation in Ukraine and abroad: infrastructure development and the legal status of ports]. Porivnjaljno-analitychne pravo - Comparative and analytical law, 4, 106-108. Retreived from: http://www.pap.in.ua/4_2017/30.pdf [in Ukrainian]

3. V Chernomorskom basseyne ozhidaetsya rost fidernyih perevozok (2016) [In the Black Sea is expected to increase feeder transportation]. Portyi Ukrainyi - Ports of Ukraine, 8, $26-28$ [in Russian].

4. Vantazhni perevezennja vnutrishnimy vodnymy shljakhamy [Freight transportation by inland waterways] www.eu4business.eu.

Retreived

from: http://www.eu4business.eu/files/medias/regulation.gov_.ua_vantazhni_perevezennya_vnutrishnimi_vodnimi _shlyahami_final.pdf [in Ukrainian]

5. Ukrajinsjkyj richnyj flot [Ukrainian river fleet]. ukrrichflot.ua. Retreived from: http://ukrrichflot.ua/ua [in Ukrainian]

6. Vantazhoperevezennja po Dnipru zbiljshylysja na $26 \%$ u 2017 roci [Cargo transportation on the Dnieper has increased by $26 \%$ in 2017] cfts.org.ua. Retreived from: https://cfts.org.ua/news/2018/01/18/gruzoperevozki_po_dnepru_uvelichilis_na_26_v_2017_godu_45059 [in Ukrainian]

7. Richkova informacijna sluzhba Ukrajiny [River Information Service of Ukraine]. ukrris.com.ua. Retreived from: https://ukrris.com.ua/ris/fairway/waybills/index.php [in Ukrainian]

8. Khto, skiljky i chogho pereviz richkamy Ukrajiny u 2018 roci [Who, how much and what was transported by the rivers of Ukraine in 2018] ports.com.ua. Retreived from: https://ports.com.ua/uk/articles/kto-skolko-i-chego-perevez-na-rekakh-ukrainy-v-2018-godu [in Ukrainian]

9. Shandrivsjka O. Je., Vysocjkyj M., Krykavsjkyj Je. V. (2017). Doslidzhennja strateghichnykh perspektyv rozvytku richkovykh portiv Ukrajiny [Research strategic prospects of development of river ports in Ukraine]. [in Ukrainian]

10. Najbiljshi porty SShA [The biggest ports of the USA] usa-info.com.ua. Retreived from: http://usainfo.com.ua/ports-usa/symbol/ports [in Ukrainian]

11. Kontejnerni perevezennja - kljuch do jevropejsjkogho rynku [Container transportations - the key to the European market] info.uz.ua. Retreived from: https://info.uz.ua/analitika/konteynerni-perevezennyaklyuch-do-evropeyskogo-rinku [in Ukrainian] 